\title{
The Politics of History and Memory in Early Chicana/o Theatre
}

\section{Jorge A. Huerta}

\section{Introduction: On Memories of George Woodyard}

While not a theatre artist himself, George Woodyard's fascination with the theatre and, particularly, his founding and editing of Latin American Theatre Review, prompted and formed the careers of many scholar-practitioners working in the field today. Through George's generosity with his time, wisdom, publications, and the periodic "Latin American Theatre Today" gatherings, he helped nurture and inspire many people to investigate Latin American and Latino theatre as praxis and theory. The theme of this special issue dedicated to Prof. Woodyard is apropos of the current conversation(s) about memory. The term "memory" has always been charged. Whose memory are we talking about? The writer's? Or, perhaps, the reader's? As this issue demonstrates, my fellow authors and countless others who were touched by George Woodyard have many fond memories of the man; the following is a brief synthesis of mine.

Whether you just witnessed an accident or are recalling something that happened long ago, who is to say that what you remember is accurate? More to the point of this discussion, how many times have you walked out of a play with a companion and either cannot remember what you just saw because it was not memorable or disagree on what you both just witnessed? Memory is witnessing; historical memory is charged with the political in that the person calling up the images that $\mathrm{s} / \mathrm{he}$ is trying to recapture becomes an interlocutor between the past and the present. What you think you saw and what you actually saw can be quite distinct, especially when time has passed.

I was recently struck by the following observation about memory written by photographer Sally Mann in the prologue to her memoir, Hold Still: A Memoir with Photographs. She writes: 
I had learned over time to meekly accept whatever betrayals memory pulled over me, allowing my mind to polish its own beautiful lie. In distorting the information it's supposed to be keeping safe, the brain, to its credit, will often bow to some instinctive aesthetic wisdom, imparting to our life's events a coherence, logic, and symbolic elegance that's not present or so obvious in the improbable, disheveled sloppiness of what we've actually been through. (xiii)

And so it is when we try to remember events, important moments, and people. I read Mann's elegant statement as a description of what all theatre attempts to do, transposing the "we" to "they." I envision the playwright organizing the "disheveled sloppiness of what [the characters] have been through" as well as "polishing the beautiful lies" that underscore each character's memories, their histories. But to take Mann's metaphor even further, I transpose the "brain's aesthetic wisdom" to the wisdom of the hegemonic powers that have determined how much we need to know about historical atrocities and elisions.

And although this special issue addresses the theme of the politics of history and memory in Latin American theatre, I come to this conversation as a professional director as well as a theatre historian with a concentration in Chicana/o theatre and performance. I have also been directing and teaching the plays of Chicana/o, Latina/o, Caribbean, and Latin American authors for many years. But my focus here will be on the Chicana/os, which demands a discussion of politics as well as memory - or are the two interchangeable?

When writing about the history and evolution of Chicana/o theatre, the political is always implicit, because the very term "Chicano" is heavily invested in its genesis as a people's term. Nobody can say with certainty where the term originated, but in the tumult of the 1960s and 70s, Mexican-American students and leftists adopted the term as a declaration of independence from the (internal) colonizer. "No more "hyphenated-American," they shouted, chanting, "Chicano Power!" while searching for their history as a people both in the United States and Mexico - a history of which they had no memory unless it had been handed down orally by their parents and grandparents. And to elaborate on Mann's observation, did the parents "polish their own lies" in order to protect their children from harsh truths about Mexicans' history in the United States?

To give a personal example, the history of the Zoot Suit riots, which occurred the year I was born, 1942, was "polished" by my parents and older sisters, who had been there, growing up in Los Angeles, where the so-called 
riots occurred. They "polished the lie" by never telling us about it in order to shield us from the realities of racism and anti-Mexican fervor that have always existed wherever there are Mexicans or people of Mexican descent in this country. Thus, the Chicano Movement was born out of anger, frustration, and the goal of unraveling the Chicanos' history, their mythos, the his-tory of polished lies, burnished so carefully that we believed them.

Because I have been researching and writing about the contemporary Chicano Theatre Movement while it has been happening, I have been living the history, watching it unfold. Therefore, my research labs have been in rehearsal halls and public performances, in parks, on campuses, and in the many theaters where I have directed throughout this country and abroad. Several years ago, I was guest-lecturing at a university and stated that the title of my presentation was "The History of Chicano Theatre," when a student blurted, "You are the history of Chicano theatre!" We all laughed (and I felt much older), but his observation caused me to pause and reflect. If I was the history of Chicano theatre, what did that mean? In effect, this is my memory play: the musings of 45 years as a director and a scholar searching for the politics of history and memory in Chicana/o theatre. The following are the reflections of a Chicano who has attempted to correct the lies, not by polishing them, but by removing the polish and exposing the unwanted truths.

Research into Chicana/o theatre and performance is all about the absence of institutional memory - the elision of our place in the "American" imaginary, an elision that can only be termed political. And this was especially true in 1968, when the first issue of this journal was published. Indeed, 1968 was a cosmic year worldwide; the period of the 1960s and early 70s was rife with leftist movements and mass demonstrations around the world. Coincidentally, 1968 was especially important for me, because that was the year I first witnessed the Teatro Campesino. I was a Mexican-American high school drama teacher in rural Riverside, California, with no knowledge of theatre created by and about Mexicans, Mexican-Americans, and the emerging revolutionaries calling themselves Chicanos.

I do not have to think hard to visualize that raggle-taggle troupe, led by one Luis Valdez, reading the now iconic poem "I Am Joaquin" by the late Rodolfo "Corky" Gonzalez, while slides of the Chicanos' troubled history were projected onto a screen to underscore the poet's passionate, angry, and prophetic words. ${ }^{1}$ To complete and complement the event, the musicians sang huelga songs in Spanish and Spanglish, echoing the poet's celebration of the Chicanos' linguistic distinction. ${ }^{2}$ That performance was life-changing, 
inspiring me to dis-cover more about this thing called Chicano theatre, to lift the cover of silence. Two years later, I entered the doctoral program in Dramatic Art at the University of California, Santa Barbara, which is when I first encountered the name "George Woodyard."

My goal in my graduate studies was to direct, research, and write about Chicano theatre; something no other doctoral student of theatre had done. When I went to the Santa Barbara library in search of information about "Chicano theatre," I found only a few references to "Theatre: MexicanAmerican." But to my surprise, my search also led me to the premiere issue of The Latin American Theatre Review, published in 1968 and edited by one George Woodyard. Thus, I first met Prof. Woodyard in print as I eagerly read the journal and the first publication in English of the classic Maya Quiché ritual dance-drama, the Rabinal Achí. Of course, I had never read this play in Spanish (or any other language); as a theatre major in the United States, one is seldom introduced to theatre from the Spanish-speaking world today, much less in 1960, when I first started studying dramatic art as an undergraduate. Indeed, most of the scholarship I discovered in 1970, aside from journal and newspaper reviews of the Teatro Campesino, were articles and dissertations about the Spanish-language folk theatre of the Southwest, articles written mainly by cultural anthropologists, not theatre historians. Yet this information was very important to a young theatre historian and practitioner/scholar looking for his theatrical roots.

Discovering the Rabinal Achi was a very propitious beginning of my investigation into the indigenous roots of Chicano theatre, because when I first met Luis Valdez in 1971 and told him what I was doing, he solemnly intoned in his deep radio voice: "Study the Maya; study the Aztecs." And because of that initial issue of the Latin American Theatre Review, I had already begun this life-long endeavor. Valdez was delighted that I was a doctoral student of theatre and even more pleased when I showed him a copy of Marilyn Ekdahl Ravicz's Early Colonial Religious Drama in Mexico: From Tzompantli to Golgotha, published in 1970 - the first volume of its kind. In 1973, Latin American Theatre Review published my review of Ekdahl's book as well as an article about the emerging Chicano theatre and thus my life-long relationship with the journal and its founding editor began. But it would take several years for me to meet the man in person.

In 1979, Prof. Woodyard and I attended the "Simposio de teatro latinoamericano: muestra venezolana," organized by Dr. Susana Castillo at California State University, Los Angeles. Prof. Woodyard and I participated in a 
mesa redonda titled "Caminos del teatro latinoamericano contemporáneo," he discussing the field in general while I addressed how I thought Chicana/o theatre practitioners were indebted to their Mexican historical and political predecessors. ${ }^{3}$ I began to know Prof. Woodyard further when I attended the first "Latin American Theatre Today" symposium/congreso hosted by the University of Kansas in 1982. I also met George's lovely wife, Eleanor, and another wonderful friendship was born. Eleanor was an incredibly gracious hostess, opening their beautiful home to the participants for the clausura, welcoming scholars, students, and theatre artists from all corners of the Americas. During that early period, I was the only person specializing in Chicano theatre as a director and a scholar at a theatre conference of any kind, and I welcomed the opportunity to find out what our Latin American colleagues were doing. ${ }^{4}$ It was also an opportunity to represent $\mathrm{La}$ Chicanada to people who knew little or nothing about the theatre of the Chicanas and Chicanos. Along with panels, there were performances of plays en español, perhaps a first for the University of Kansas. The symposium was a wonderful event, and lasting friendships and networks were formed that continue to this day, thanks in large part to that gathering and subsequent symposia hosted by the University of Kansas and other universities into the first decade of the $21^{\text {st }}$ century.

When I told my colleagues in California that I had attended a conference on Latin American theatre in Kansas, they were somewhat surprised. Who knew that Latin America was of interest to scholars in the Heartland? Further, how many scholars (outside of Latin Americanists) knew that the Center for Latin American and Caribbean Studies at the University of Kansas had been founded in 1961? Even my theatre colleagues and Chicano Studies scholars in other disciplines on my campus were surprised to find out that a journal published in Kansas would be interested in Chicano theatre and performance. Due to George's continued interest in the field, I published my second article about Chicano theatre for the journal in 1977 and joined the Editorial Board in 1989.

It took the Woodyards 10 years to "recover" from that initial symposium, after which they hosted the closing reception for the second "Latin American Theatre Today" symposium in 1992, followed by ever-growing symposia in 1997, 2000, and 2003. Each of the gatherings was like a homecoming for those of us who had attended the earlier symposia over the years, and when we gathered in 1997, we were already welcoming a new crop of graduate students and young scholars and artists dedicated to the research, performance, 
and dissemination of Latin American theatre-young scholars who had no doubt been influenced by their professors and the Latin American Theatre Review. We now also had an emerging group of scholars and artists writing and performing theatre by and about Chicanos, Puerto Ricans, and Cubans in the United States. Thus, the Latin Americanists were being exposed to the Latinas and Latinos and vice versa. These exchanges across borders became an important element in the development of Chicana and Chicano theatre.

\section{Back to the Origins: The Politics of History and Memory in Early Chicano/a Theatre}

What I now want to explore is how I witnessed and participated in the evolution of Chicana/o theatre in its initial manifestations, when the early Chicano theatre companies began to re-write and explore the history of politics and memory through their collective performances. In keeping with the theme of this issue, the following discussion will highlight the influence of Mexican and Latin American theatre companies and artists on what became the Chicano Theatre Movement.

I return to that evening in 1968 when I first witnessed the Teatro Campesino in a performance at the University of California, Riverside. Along with the slide show underscoring "Corky" Gonzalez's poem "I Am Joaquin," the farmworkers-cum-actors performed actos (political sketches) about the need for a union. Soon after its inception, the Teatro Campesino had begun to perform on college campuses, in union halls, and at other venues in order to raise awareness of the issues as well as to generate much-needed revenue for the union's coffers. The Great Grape Boycott of 1965 was in full effect, and the Teatro Campesino can be credited with bringing national and even international attention to the farmworkers' need for a union and collective bargaining. The early actos employed farce, stereotypes, and commedia dell 'arte techniques to satirize the wealthy growers and their henchmen while demonstrating the power of Unity. The actos were what I have termed modern morality plays pitting Good (el Campesino) against Evil (el Patrón). Collectively created under Valdez's leadership, the actos brought much-needed awareness, enhanced by laughter, to a dire situation.

In 1967, Valdez told an interviewer, "We use comedy because it stems from a necessary situation - the necessity of lifting the morale of our strikers... This leads us into satire and the underlying tragedy of it all - the fact that human beings have been wasted in farm labor for generations" (Bagby 77). The actos ended with the grower signing a union contract, a symbolic 
but powerful triumph. The Teatro Campesino helped the striking farmworkers recognize that they were not alone, that there were supporters from all walks of life who wanted to help them achieve a dignified life.

The Teatro Campesino gained international attention when the troupe attended the "Theâtre des Nations" in Nancy, France, in 1969. This international theatre festival introduced Valdez and his troupe to other world-class theatre companies and artists, underscoring the importance of networking and learning about various styles of performance from around the world. The Nancy festival undoubtedly inspired the Teatro Campesino members to host the first Chicano Theater Festival at their storefront theatre in Fresno, California, in 1970. The Teatro Campesino had been planting seeds of creativity wherever it had performed, especially on college and university campuses where new teatros were being formed in order to enhance efforts to educate their communities about their history and the need for social justice. Aware of this growing trend, the Teatro Campesino members were eager to gather groups from across the country to assess the state of the emerging Chicano theatre. What were they saying and how were they delivering their message(s)? Approximately 13 groups participated in the 1970 festival, including a Puerto Rican troupe from New York City called Los Reveladores del Tercer Mundo and a group from Mexico City called Grupo de Poesía Coral los Mascarones, directed by the late Mariano Leyva. This gathering proved an important step in the evolution of a pan-Latino consciousness, with individuals and troupes from coast-to-coast attending, all seeking to reveal their truths and to improve their craft.

The first festival inspired the members of the Teatro Campesino to organize and host a second Chicano Theatre Festival the next year, 1971, on the campus of the University of California, Santa Cruz. My wife, Ginger, and a group of undergraduate students under my direction at the University of California, Santa Barbara, had formed El Teatro de la Esperanza in 1971 and elected to participate in this festival. This was my first exposure to a Chicano theatre festival, an essential and eye-opening introduction to some of the individuals and groups dedicated to the nascent field. It was clear from what we witnessed at the festival that there was a wide disparity of theatrical experience among the young participants, including some of our own teatro members. Although Valdez and I had the most theatrical training and experience, the majority of the teatristas were university students with little or no training in the theatrical arts and most were not theatre majors. However, that lack of experience was why Valdez's troupe initiated the annual festivals: to 
offer participants guidance on how to reach their communities with theatre that, like the Brechtian ideal, was both transformational and entertaining. In other words, theatre that would uncover the lies.

Following the second festival, representatives of several teatros met at the University of California, Santa Barbara, hosted by El Teatro de la Esperanza. Of course, everyone was looking for words of advice and wisdom from the man who, along with his teatro members, had inspired the emergent Chicano Theatre Movement. I will never forget the moment when a young Chicano asked Valdez, "If a Chicano paints a vase of flowers on a canvas, is that a political act?" To which Valdez quickly replied, "Yes, because that Chicano had the time to paint the vase of flowers on a canvas." Recall that this was a time of radicalism fueled by worldwide opposition to the war in Vietnam and amplified by the Chicano and Civil Rights movements. Indeed, in protest of the war, students from the Santa Barbara campus had gained national and international attention by burning down the Bank of America next to the university in the spring of 1970 just prior to my arrival with my family.

These were heady times, so a vase of flowers painted on a canvas had no signifiers we could read back then. A vase of flowers could hardly be termed "political," we thought, even if Valdez had recognized the semiotics of it all. We did not think about the socioeconomic factors implicit in that supposedly non-political painting: Where did the artist get the funds to pay for the paint, canvas, frame, brushes - the space to create? I ask today a political question that begged attention then and now. However, the representatives of the various teatros returned to their respective university campuses and community centers and continued to collectively create and perform their own actos, because those were the only living models they had. Well aware of the fact that there were no plays by or about Chicanos in print, in 1971 the Teatro Campesino published an anthology of their now-classic actos, which had been created and performed between 1965 in 1971. Further, the Teatro Campesino members gave permission to the other teatros to perform the actos without paying royalties. Many young teatros, including Teatro de la Esperanza, took advantage of this generous offer as we learned how to create our own stories using the conventions of the acto. The actos dramatized the problems faced by farm workers as well as other prominent issues, including the lack of educational opportunities, exposure of the vendido, or sell-out who denies her/his Mexican heritage, and the ravages of the war in Vietnam.

There was no time for social realism or any kind of theatrical realism in that period of improvisation and street theatre. For most of the young 
teatro activists, in order to be considered authentically "Chicano," cultural expression had to be "politics before art," the message more urgent than the medium. The performers in the early teatros were more like "social workers" than cultural workers and they were fine with this, eager to speak the truth to their communities as they educated and motivated their audiences to take action against any number of injustices. Furthermore, actos were meant to address current issues in large brushstrokes with exaggerated situations and props because they were often performed at outdoor political rallies. There was no room for "kitchen-sink dramas" under those conditions.

Meanwhile, Chicano and Chicana muralists were looking for their histories by painting on barrio walls, and if there were any flowers on those walls, they were probably at the foot of an image of La Virgen de Guadalupe, who validated the Chicanos' religious and historical roots. Many murals also contained iconic images of the Aztec and Maya cultures, juxtaposed with historically important (male) liberators such as Father Hidalgo, Emiliano Zapata, and Pancho Villa. Often prominent among the historical heroes was the face of the living legend César Chávez. Alongside the symbol of the farmworkers union, the huelga flag, political chants such as "Chicano Power!" or "iRaza sí, Guerra no!" were prominently displayed. Because the Chicana/o visual artists were making their marks on outdoor walls - frozen tableaux depicting the political history of the Chicana/os - people could see them en vivo at any time or study them in the many reproductions that were being circulated in journals, magazines, and books. And even though they had no memory of the historical figures they were reproducing, the early visual artists were making political statements just as the Chicano teatros were attempting to do. Like the early teatros, many of the muralists were just beginning their art. They were all in need of further training if their art was to gain attention, whether it was painted on a wall or performed on a stage. While many visual artists worked in isolation, or with student assistants, the teatros were creating ensembles and were forming a network that would enhance their aesthetic and political growth as cultural workers.

Following the two initial Chicano Theatre festivals, TENAZ, the acronym for El Teatro Nacional de Aztlán, was founded by Chicano and Mexican theatre groups under the leadership of the Teatro Campesino, Los Mascarones, and other Chicano theatres. The name was suggested by Mariano Leyva, whose brilliant rhetoric in Spanish always awed and inspired the Chicanos, whose Spanish had been taken away by the schools or by their parents, who did not want them to suffer the linguistic discrimination they had experienced 
in their youth. Thus, when Mariano spoke, we listened attentively. We learned that tenaz meant "tenacious," and we knew that the term Aztlán is Nahuatl for "the land to the North; the land from whence the Aztecs came." The Chicano activists of the 1960s interpreted Aztlán to mean the Southwestern United States, which had been populated by indigenous peoples before Westward Expansion and the signing of the Treaty of Guadalupe Hidalgo in 1848, when the Mexicans suddenly became strangers in their own land. Several generations later, the Chicano activists would shout, "We didn't cross the border; the border crossed us!" as they searched for their erased histories through their music, art, folkloric dance, poetry, and theatre. Over the years, TENAZ leadership organized national festivals and workshops that, like the first two festivals, included Mexican, Puerto Rican, and other non-Chicano theatre artists working in the field in an effort to enhance this incipient movement.

Also crucial to the aesthetic and political growth of the young activistscum-actors was the insight imparted by our Latin American colleagues during the "Quinto Festival de los Teatros Chicanos: Primer Encuentro Latinoamericano," organized and hosted by TENAZ, Mascarones, and El Centro Libre de Experimentacíon Teatral e Artística (C.L.E.T.A.) in Mexico City and Tajín, Veracruz, for two weeks in the summer of 1974. This was a historic and lifechanging event for many of the participants from the United States. Eager young Chicanas and Chicanos were introduced to internationally recognized theatre artists such as Emilio Carballido, Augusto Boal, Enrique Buenaventura (Teatro Experimental de Cali), and Santiago García (La Candelaria, Bogotá, Colombia), among other significant leaders in the field. ${ }^{5}$

The influence of these Mexican and Latin American theatre artists was crucial to the political and aesthetic growth of Chicana/o theatre even before the 1974 festival. Members of our nascent Teatro de la Esperanza first met Enrique Buenaventura in 1972 at the "First Latin American Theatre Festival," hosted by the University of San Francisco, California. We performed Brujerías by Rodrigo Duarte-Clark, a simple one-act comedy that centers on an old Mexican couple that calls La Migra (Immigration) to report a Mexican woman whose house they want. In a satiric jab at (Roman Catholic) superstition, the couple believes that the old woman is "una bruja." I'll never forget what the Maestro said to us after the performance: "The more specific you become about your community, the more universal the work will be." Aside from the Teatro Campesino, these were the days when teatro performances were being criticized by mainstream newspaper critics, who complained that the Chicanos' plays were not "universal." It took a colombiano to help us see 
that the struggles and frustrations, the trials and the triumphs of La Chicanada were, indeed, universal, that our lives mattered as historical documents that would one day constitute a collective memory.

Buenaventura also understood that we were "en la barriga del monstruo," and used that term to identify the Chicano's socioeconomic condition, our internal colonization, as it were. He understood us, perhaps, better than we understood ourselves. And when we witnessed his company performing his brilliant allegory La orgía - a production I can still visualize — we knew we were in the presence of a master and a brilliant ensemble. We ran to read his plays and learn his philosophy and theories of a collective people's theatre, teatro colectivo para la gente. And, of course, we read the Latin American Theatre Review for further references to the developing nuevo teatro popular de Latinoamerica. ${ }^{7}$ I can honestly say that the 1972 encounter with Buenaventura and his ensemble turned the members of our teatro into true believers in theatre for social change, and as we drove back to Santa Barbara we all vowed to dedicate our lives to teatro. And many of us did.

We learned a great deal from Buenaventura and I, for one, use his techniques to this day. He taught us how to investigate, how to collaborate, and how to create the best teatro that we could. In fact, Teatro de la Esperanza collectively created the first Chicano docu-drama, Guadalupe, in 1974, a project that was enhanced by our knowledge of the Teatro Experimental de Cali collective creation process. ${ }^{8}$ Over the ensuing years, I found myself in the presence of Buenaventura a number of times, in the U.S., Mexico, and Colombia. But the image I will always have of this great man was when he and I directed our distinct versions of La maestra, from his Papeles del infierno, at the University of California, Irvine, in 1990. We worked separately, I in English and he en español, with the same group of graduate student actors and the two directors in the Hispanic-American Graduate Theatre Program at the University of California, San Diego. ${ }^{9}$ The actors and the two assistant directors were sworn to secrecy, and thus neither Buenaventura nor I (nor our assistant directors) knew how the other was directing the piece until the students performed the play for the participants in the conference.

To everyone's surprise and delight, Buenaventura had placed himself in the piece as the father, a sad, tired old man about to be killed by the State torturers. All eyes were on that man, whose stillness only enhanced the pathos. Those of us in the audience who knew who he was could not help but think that there, dressed in humble campesino clothing, playing a man about to die with such dignity was one of los hombres grandes del teatro latino- 
americano. He knew how to create images that live forever, images of the death and destruction wrought on his country by inside and outside forces. ${ }^{10}$

Most importantly, the Mexican and Latin American playwrights and directors who participated in the many TENAZ festivals in the years between 1970 and 1993 taught the Chicana/os and other Latina/os a great deal about how to explore and expose the political history of problems inherent in the United States. We learned that political theatre could be didactic yet entertaining by employing political metaphors and symbolism as well as farce. Through the $1960 \mathrm{~s}$ and 70s, the acto form was still the core of many teatros' aesthetic practice; the groups were dependent on improvisation, because there were few published plays about the Chicanos' experiences. The lack of plays prompted me to publish an article aptly titled "Where Are Our Chicano Playwrights?" in $1975 .{ }^{11}$ Enter Emilio Carballido to lead the way.

A major influence on budding Chicana and Chicano playwrights, Carballido participated in several TENAZ festivals, observing, speaking, and conducting workshops in playwriting to the delight of the participants. In post-performance discussions, his insights into the Chicanos' realities, as a Mexican, enhanced understanding of who these marginalized people were. Carballido was an honest but sensitive respondent to the developing plays and performances he witnessed in his workshop or in the daily performances at the festivals. He knew how to give constructive criticism and was generous without being condescending. His gracious demeanor made everybody comfortable and engendered a positive energy that only a maestro can achieve. Carballido would also return to San Francisco, California, to conduct summer playwriting workshops organized and hosted by members of Teatro de La Esperanza, who were now based in that city, thus expanding his reach beyond the yearly TENAZ festivals. It must be noted, however, that Buenaventura and Carballido are only two of the many theatre artists from Latin America who have made an impact on the politics of history and memory in Chicana/o theatre. ${ }^{12}$

\section{Conclusion: Making the Invisible Visible}

Much has happened in the years following the early period of Chicano theatre that I have discussed above. While very few of the groups that were active in the early years of TENAZ exist today, the legacies of the early teatros are evident in the many Latina and Latino theatre artists and theatre companies operating today. When people ask me, "What happened to the early teatros?" I answer rather mischievously, "They had children." And they did. 
But with families to support, most teatro members moved on to other fields, applying what they had learned about their histories and the importance of uncovering the lies to other professions, including social work, education, medicine, law, community activism, and even politics. Other people began new teatros, expanding the reach of a movement that began before many of the new generation of teatristas were born.

By the 1980s, individual playwrights began to emerge, especially the Latinas, some with graduate degrees, others working with theatre companies dedicated to the same goals as the early TENAZ teatros. The acto was no longer the foundational aesthetic, as playwrights began to create works that explored and exposed the "Latina/o condition" in a variety of genres more subtle in their politics. Furthermore, the emerging playwrights were creating plays that, unlike the very portable actos, required theatre facilities and a level of artistic professionalism not evidenced in the early period of Chicano theatre.

By the end of the $20^{\text {th }}$ century, the Chicano Theatre Movement had transformed into a Latina/o Theatre Movement, as groups from coast-tocoast began to refer to themselves as Latina/o theatre companies. In the year 2012 , individual theatre artists and theatre companies began to organize on a national scale and founded the Latino Theatre Commons as a component of Arts Emerson at Emerson College, in Boston, Massachusetts. This is a national advocacy organization, not unlike TENAZ, dedicated to the growth and development of Latina/o theatre. Regional alliances have been formed from coast-to-coast, and national gatherings are giving a structure and network to this new Latino Theatre Movement. ${ }^{13}$

The politics of history and memory are more than just personal, intuitive responses to our world as we think we knew and know it. Through festivals, publications such as this one, and the many exchanges that have occurred between theatre artists from all of the Americas, the lies will have lost their burnish as long as there are artists willing to challenge the status quo, on the streets, in the schools, and in venues across the nation and beyond. And we must never forget the influence of George Woodyard as one of the people who brought us all together.

\section{University of California, San Diego}




\section{Notes}

1 Rodolfo "Corky" Gonzalez's poem, "I Am Joaquin," is in his book Message to Aztlan (Houston: Arte Público Press, 2001):16-29. The poem was first published in 1967.

2 Spanglish was the code-switching I had grown up speaking, to the utter consternation of my proud, Mexican-born father. "Háblame en español, no como un pocho!" he would demand.

3 See Jorge A. Huerta, "Simposio de Teatro Latinoamericano: Muestra Venezolana," Latin American Theatre Review 12.2 (1979): 79-80.

4 When I say I was the only Chicano theatre director and scholar at a theatre conference of any kind, I am referring to the American Educational Theatre Association (AETA) conferences I began to attend in the mid-1970s. For many years, I remained the only person researching and directing Chicano theatre at these conferences. I am happy to report that the field has grown incredibly. Perhaps as proof of how far we've come in the Academy, Patricia Ybarra is now the President of the Association for Theatre in Higher Education (ATHE) and professor of Theatre at Brown University. Furthermore, the Latino Focus Group of the ATHE numbers well over 40 individuals.

5 For an excellent analysis of the "Quinto Festival de Teatros Chicanos: Primer Encuentro Latinoamericano," see Alma A. Martínez. “¿Un continente, una cultura?: the political dialectic for a united Chicana/o and Pan-American popular/political theater front, Mexico City, 1974." Diss., Stanford University, 2006. ProQuest Dissertations and Theses. Web.

6 Brujerías is published in Jorge A. Huerta, El Teatro de la Esperanza (Goleta, CA: Teatro de la Esperanza, 1973): 39-62; and in Revista Chicano-Riqueña 7 (1979): 9-17.

7 See Judith A. Weiss, Leslie Damasceno, and Donald Frischmann, Latin American Popular Theatre (Albuquerque: U of New Mexico P, 1993), for further information.

8 Guadalupe is published in Jorge A. Huerta, Necessary Theater: Six Plays About the Chicano Experience (Houston: Arte Público Press, 1987): 208-57.

9 I had the honor of heading the first (and only) class of the Hispanic-American Theatre Program from 1989 to1992, along with the late Prof. Tony Curiel and other faculty members. Records of this program are in the Jorge Huerta Papers, University of California Special Collections.

${ }^{10}$ For an excellent discussion of the two versions of Buenaventura's play at the University of California, Irvine, see Diana Taylor, "La maestra: Dos representaciones/ dos cosmovisiones," Gestos 6.11 (1991): 205-12.

${ }^{11}$ See Jorge A. Huerta, "Where Are Our Chicano Playwrights?" Revista Chicano-Riqueña 3.4 (1975): 32-42.

${ }^{12}$ For more information on the importance of Latin American theatre artists in the Chicano Theatre Movement, see Jorge A. Huerta, "The Influences of Latin American Theatre on Teatro Chicano." Revista Chicano-Riqueña 11.1 (1983): 68-77.

${ }^{13}$ For a discussion and review of the Latino Theatre Commons/Los Angeles Theatre Center's "Encuentro 2014," a month-long national festival of Latino theatres from the United States and Puerto Rico, see Jorge A. Huerta, "Encuentro 2014: Latina/o Theater Moving Forward," Gestos 59 (2015): 17388. In July of 2015, the Latino Theatre Commons also organized and hosted a Carnaval/Festival of new Latina/o plays at DePaul University. These events would not have been possible in the early years, when there was little access to the funding and venues for such national events.

\section{Works Cited}

Bagby, Beth. "El Teatro Campesino: Interview with Luis Valdez." Tulane Drama Review 11 (1967): 70-80. Print. 
Huerta, Jorge A. “Concerning Teatro Chicano." Latin American Theatre Review 6.2 (1973): 13-20. Print.

. Rev. of Early Colonial Religious Drama in Mexico: From Tzompantli to Golgotha, by Marilyn Ekdahl Ravicz. Latin American Theatre Review 6.2 (1973): 76-77. Print.

."Where Are Our Chicano Playwrights?" Revista Chicano-Riqueña 3.4 (1975): 32-42. Print.

. "Chicano Agit-Prop: The Early 'Actos' of El Teatro Campesino." Latin American Theatre Review 10.2 (1977): 45-58. Print.

. "Luis Valdez's Zoot Suit: A New Direction for Chicano Theatre?" Latin American Theatre Review 13.3 (1980): 69-76. Print.

. "Encuentro 2014: Latina/o Theater Moving Forward." Gestos 59 (2015): 173-88. Print.

Mann, Sally. HOLD STILL: A Memoir With Photographs. Boston: Little, Brown, 2015. Print.

Taylor, Diana. "La maestra: Dos representaciones/ dos cosmovisiones." Gestos 6.11 (1991): 205-12. Print.

Valdez, Luis Miguel. Early Works: Actos, Bernabe, Pensamiento Serpentino. Houston: Arte Público Press, 1990. Print. . "El Teatro Campesino." Ramparts 5.2 (1966): 55-56. Print. 


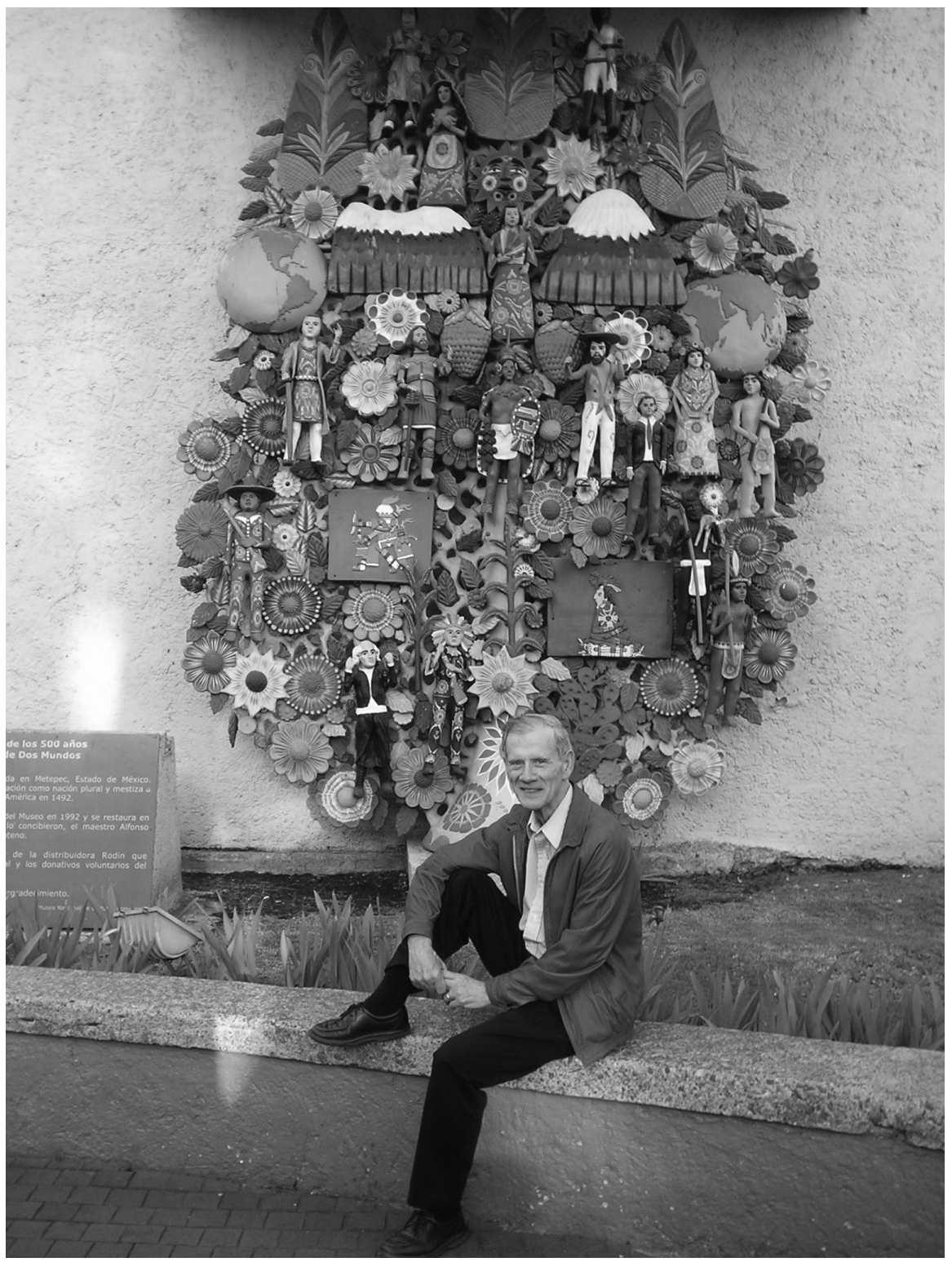

George Woodyard. Photo: Jacqueline E. Bixler. 